\title{
Judaism and Islam in Latin America and among Latin-American Immigrants
}

\author{
Frank Usarski ${ }^{1}$
}

Published online: 19 June 2019

(C) Springer Nature Switzerland AG 2019

The responses to our call for papers for the thematic session of this issue have fulfilled the expectations of the editorial team. Although Judaism and Islam in Latin America and in Latin American Diasporas abroad are not central to the common scientific agenda, the research of related topics and its stimulating results are highly welcome for readers interested in a comprehensive and detailed account of the situation in countries which are of primary relevance for the International Journal of Latin American Religions. Under these conditions, we have selected seven papers among the articles submitted during the last months.

The first article, "The Framing of Kirchnerism Among Jewish Ethnic Entrepreneurs: A Case of the Interrelation Between Ethnicity and Politics," focuses on the antagonistic positions of the group Llamamiento Argentino Judio and the Jewish newspaper Comunidades towards the ideological orientation of Néstor Kirchner and Cristina Fernández de Kirchner during their subsequent presidencies (2003-2015). According to the author, the statements of the two agencies reflect deeper rooted conflicts among Argentina's politically diverse Jewish population. As such, they are instrumental for the analysis of different modes of defining Jewishness and the ways the Jewish minority relates to the wider Argentinean society.

In her article, "Brazilian but Jewish: Religious Conversion and Mismatched Identities," Sarah Leiter shares with the JLAR readers the findings of her field study of an unconventional local synagogue in Brazil's capital, Brasília, made up by some thirty Brazilians who understand themselves as converts to Judaism without having gone through an authorized introduction to Judaism or a formally recognized conversion procedure. Committed to the anthropologist principles of suspension of majority-based judgments and empathy with the self-understanding of the subjects under study, the author is interested in the ways the group members manage to maintain their dual identification as Brazilians and Jews within a traditionally Christian country and despite their non-acceptance by official Jewish institutions.

Frank Usarski

usarski@ymail.com

1 Pontifícia Universidade Católica de São Paulo, São Paulo, Brazil 
The following article, "Drawing the Boundaries of Non-Catholic Religions in Argentina and Brazil: Conversion to Islam and the Return to Orthodox Judaism (Teshuva)," written by Batia Siebzehner and Leonardo Senkman, is based on a field study of in-the-past religiously indifferent but now re-committed orthodox Jews and converted Muslims in Buenos Aires and-to a lesser extent-in São Paulo. The authors discuss significant differences between the two objects (for example, Argentina versus Brazil; particularistic Judaism versus universalistic Islam) as well as common denominators (such as religious individualization as a consequence of secularization or the role of the internet as a source for information and stimulus for personal choices) and analogous challenges (e.g., possible tensions between the "returned" or converted individual with incomprehensive family members).

While Siebzehner and Senkman focus on individual believers, Cynthia Hernandez Gonzalez's article, "The Nur Ashki Jerrahi Tariqah in Mexico City: A Branch from Istanbul's Halveti Jerrahi Tariqah," is interested in a specific religious institution. The author also expands the substantial scope by adding Mexico to the list of considered countries within the thematic session. The paper offers an overview of the history, teachings, and activities of the dependence of the Halveti Jerrahi tariqah (founded in 1740 in Istanbul) in Mexico City (established in 1987) by Lex Hixon, better known under his Sufi-name Shaykh Nur al-Anwar al-Jerrahi. The Shaykh's institutional legacy also includes the Light Within Light Institute (founded in 2000). In accordance with the principles of Nur Ashki Jerrahi Tariqah, the institute shows openness towards the feminine and the role of women within the organization and engages itself in interfaith dialog.

In their article, "Muslims in Brazil and Mexico: A Comparative Quantitative Analysis," Cristina Maria de Castro and Elaine Meire Vilela offer a succinct overview of the history and current state of institutionalized Islam as well as a summary of relevant data concerning the Muslim communities resulting from the Brazilian and Mexican censuses conducted in 2010. In the related paragraphs, the reader finds information concerning the approximate number of individual Muslims and their socioeconomic and demographic profiles including aspects such as the proportion between men and women, median age, level of education, employment, and more specifically occupation. Against the background of these data, the authors approach the overall situation of a minority religion that once was brought to Latin America by immigrants and is now undergoing significant changes due to the affiliation of a considerable number of converts who - as well as Muslims stemming from immigrant families - have to come to terms with anti-Islamic prejudices against their religious beliefs and routines.

The last two articles of the thematic session refer to Islam among Latin Americans who live in the USA. In her paper, "Politics of Spirit: Latin Muslim in Los Angeles, CA", Arely Medina calls attention to the functionality of ethnicbased denominations as intermediating instances between immigrants and the State. On the one hand, by preserving the cultural heritage within a transplanted religion, the group serves as a tool for demarcating the collective identity of the adherents. On the other hand, by publicly representing the adherents (for example in interfaith meetings), offering social assistance as institution, and promoting mutual help among its members, the community plays an integrative role from 
the perspective of the wider society. In this sense, a denomination transcends its religious core purpose and engages itself in the "politics of spirit." The author exemplifies these more general reflections by describing the activities of the Los Angeles Latino Muslims Association (LALMA) which is active within an urban space known for its multi-religious and pluri-ethnical configuration.

Harold D. Morales discusses in his article, "Latino Muslim by Design: Names, Descriptions, and Identity Politics," the ambivalent outcome of Latino-Muslim organizations in the USA which operate in favor of combating a negative public image through the construction and promotion of a corrective narrative. Apart from its positive side, the author points to possible negative effects of interest representations of a determined group. The defense of the own community carries the risk of isolating from ambitions of other marginalized segments of the US population including the Latino minority in the USA and US American Muslims in general. Furthermore, there is the problem that the construction of an allegedly homogeneous group identity overshadows the real complexity and internal differences of the community. According to Morales, these and other topics related to the study of Latino-Islam in the USA demand from academics engaged in the research of the field a critical self-reflection on their role and implicit normative positions towards the subject under study. As Morales himself mentions, his essay makes use of a material already published in his book Latino and Muslim in America: Race, Religion, and the Making of a New Minority. The latter is recommended for readers interested in more comprehensive and detailed discussion of related topics. For this reason, a critical appreciation of the book has been included into the book reviews section of the present issue.

Besides the articles submitted in response to the call for papers on "Judaism and Islam in Latin America and Latin American Diasporas", we make another five papers accessible to our readers. In the first article of this category, "Religion and Traditional Social Elites: Argentinean Federal Judges' Current Practices, Beliefs, and Justification Ways", Luis Miguel Donatello and Mercedes Nachón Ramírez summarize the results of seventeen biographic interviews with Federal Judges mostly conducted in Buenos Aires and its surroundings with the aim to shed light on the role, importance, and meanings of Catholicism and the Church in the respondents' past and present. The discussion of these aspect leads to an analytical scheme composed by two sets of dichotomic coordinates that allows a categorization of the interviewees' involvement in the ritual life of the Church and their types of religious commitment.

Fábio L. Stern summarizes in his paper "The Religious Profile of Brazilian Alternative Therapists: The Case of Naturology" a study on the relation between Naturology, i.e., a higher education training course for alternative therapists, recognized by the Brazilian Ministry of Education, and the universe of non-conventional Spirituality. The data collected by the author proves that most of the higher education title holders in Naturology consider themselves adherents of the New Age movement. This result not only contradicts widespread contrary assessments but also indicates that the "New Age" concept did not lose its plausibility — as some researcher argue — but is still a valuable category.

In their paper "Cultural and Group Differences in Mediumship and Dissociation: Exploring the Varieties of Mediumistic Experiences", Everton de Oliveira Maraldi, Ricardo Nogueira Ribeiro, and Stanley Krippner argue that experiences and beliefs, as well as the accompanying levels of dissociation or alteration of consciousness associated to "mediumship' and "possession" cannot be reduced to a universal basis or a 
single psycho-physiological state which in the worst case is evaluated according to the psychopathological paradigm. The situation is much more complex and demands not only the recognition of cultural varieties and group differences of related experiences, but also a critical revision of concepts such as "trance" and "dissociation."

The article "New Age Spirituality in Argentina: Cultural Change and Epistemological Challenge" submitted by Pablo Semán and Nicolás Viotti is a supplement to the thematic session on "Alternative Religiosity and Non-institutionalized Spiritualities in Latin America” (JLAR 2/2018). Based on analyses of media reports, participant observation, and personal interviews, the article contributes to a deeper understanding of expressions of the so-called New Age Sprituality in the context of a traditional Catholic, but in a religious sense increasingly pluralistic country. The conclusions drawn by the authors are backed up by two empirical references. Firstly, there is the case of Claudio María Domínguez, a much-noticed personality due to his professional communicational skills, the mastering of public appearances in the mass media, and the Catholic-connoted jargon used in his commercially successful books published in the self-help segment of the wider market of New Age literature. Secondly, Pablo Semán and Nicolás Viotti discuss the Art of Living movement founded by the Hindu master Sri Sri Ravi Shankar who presents his teachings as non-religious, hence compatible with any institutionalized religion, including Catholicism. The movement is not only highly visible in the form of a vast scope of written material, but also easily accessible through retreats in which meditation and pranayama techniques are taught and explained in a common language garnished with terms borrowed from physics or psychology.

Guided by the hypothesis that "women's possession cults are 'thinly disguised protest movements' in societies where women are oppressed," Kate Kingsbury and R. Andrew Chesnut explore in their paper "In Her Own Image: Slave Women, and the Re-imagining of the Polish Black Madonna as Ezili Dantò, the Fierce Female Lwa of Haitian Vodou" the political implications of the imagery of the female spirit Ezili Dantó. The latter is one of many manifestations of the-according to its diverse historical and ethnical roots - complex Haitian Voudou pantheon. The most interesting feature among the multiple influences identifiable in Ezili Dantó's representation is the impact and resignification of the symbolism linked to Our Lady of Czestochowa, i.e., a Black Madonna, brought to Haiti by members of the Polish legion who had been hired by Napoleon in order to suppress a slave insurrection in 1802. Taken these and other metaphorical attributes into account, the authors demonstrate that Ezili Dantó "is a window into the memories, vulnerabilities, and identities of black slave women."

In addition to the twelve papers summarized above, the present JLAR issue contains a report of the XIX Jornadas sobre Alternativas Religiosas en América Latina (XIX Journeys on Religious Alternatives in Latin America), held in November 2018, in Santiago de Chile; an interview with the Peruvian author and researcher of the relation between religion and politics José Luis Perez Guadalupe, and - alongside the already mentioned review of Harold D. Morales' Latino Muslim by Design: Names, Descriptions, and Identity Politics, a critical appreciation of Cristina Rocha's book John of God: The Globalization of Brazilian Faith Healing.

Pulisher's Note Springer Nature remains neutral with regard to jurisdictional claims in published maps and institutional affiliations 